\title{
Construction and Empirical Verification of the Agri-Environmental Index (AEI) as a Tool for Assessing the Green Performance of Agriculture
}

\author{
Armand Kasztelan (D) and Anna Nowak* \\ Department of Economics and Agribusiness, University of Life Sciences in Lublin, Akademicka 13, \\ 20-950 Lublin, Poland; armand.kasztelan@up.lublin.pl \\ * Correspondence: anna.nowak@up.lublin.pl; Tel.: +48-513-131-856
}

Citation: Kasztelan, A.; Nowak, A. Construction and Empirical Verification of the Agri-Environmental Index (AEI) as a Tool for Assessing the Green Performance of Agriculture. Energies 2021, 14, 45. https://dx.doi.org/ 10.3390/en14010045

Received: 25 November 2020 Accepted: 21 December 2020 Published: 23 December 2020

Publisher's Note: MDPI stays neutral with regard to jurisdictional claims in published maps and institutional affiliations.

Copyright: () 2020 by the authors. Licensee MDPI, Basel, Switzerland. This article is an open access article distributed under the terms and conditions of the Creative Commons Attribution (CC BY) license (https: / creativecommons.org/ licenses/by/4.0/).

\begin{abstract}
In this paper, the aggregate index of green performance of agriculture (Agri-Environmental Index $(A E I))$ was proposed and empirically verified. For this purpose, a taxonomic method was used, i.e., the linear ordering method, which allows for the construction of a synthetic metric for the assessment of performance. Based on 16 agri-environmental indicators from the Organization for Economic Cooperation and Development (OECD) and Eurostat database, green performance indexes were constructed for 20 European countries. The constructed indexes are based on the multi-line impact of agriculture on the environment, with a particular focus on energy issues. During the analyses, answers to the following research questions were sought: Is the AEI an appropriate tool for evaluating the green performance of agriculture? What is the overall situation in this matter in EU countries? Which areas in terms of the impact of agriculture on the environment require remedial actions? The results of surveys show that the level of green performance in countries is still low (an average of 0.3069 ). The article indicates the areas that require special attention in the context of continuation of greening processes in the agricultural sector.
\end{abstract}

Keywords: green agriculture; agri-environmental indicators; energy efficiency; green performance index; taxonomic methods; zero unitarization method; comparative analysis

\section{Introduction}

Agriculture is a sector of the economy that has special links with the natural environment. These links are complex and reflect biological processes, changes in the natural environment conditions, socio-economic factors, and agricultural and environmental policy $[1,2]$. They are additionally compounded by a spatial variation of the impact of agriculture on the environment in different countries $[3,4]$. On the one hand, the performance of agriculture depends on land and water resources, and on the other hand, agricultural production often takes place at the expense of the environment (e.g., resulting in soil degradation, deteriorated quality of water, reduced biological diversity, increased greenhouse gas emissions), which undermines environmental sustainability [1,5-8]. Industrial agriculture was highly efficient but generated environmental and social consequences of global significance [9]. Due to the need for altering the paradigm of European agriculture after the period of industrialization, the concept of sustainable agriculture was recognized as a priority direction of development reflected in the common agricultural policy of the EU [10]. This gives rise to specific prospects for the development of this sector but also to several challenges. In fulfilling its environmental sustainability mission, present-day agriculture should integrate a wide spectrum of objectives connected with the demand for food and agricultural commodities with the environmental challenges $[8,11]$. Challenges to be faced by agriculture also include increased competition around alternative uses of the natural resources, maintaining biological diversity, food safety, and climate change mitigation $[12,13]$. This also means a need for constructing an adequate policy of energy 
efficiency in agriculture in which the effects of production are considered in terms of energy expenditure and minimization of environmental impacts.

Recently, in connection with a growing interest in environmental issues, many studies have been undertaken investigating the relationship between the economy as a whole or its respective sectors and the natural environment. One of the research lines is environmental (green) performance. Mutingi et al. [14] used the term 'green performance' with reference to supply chains. In turn, $\mathrm{Li}$ and Lin [15] extended this reference to include the economy as a whole. Gallego-Álvarez et al. [16] use 'environmental performance' and 'environmental sustainability' as alternative terms. Several papers have analyzed environmental performance in the EU from different angles. In macroeconomic terms, the environmental performance of countries is defined as a country's ability to produce environmental public goods [17]. In turn, Beltrán-Esteve and Picazo-Tadeo [18] evaluated environmental performance in the European Union using Luenberger productivity indicators and DEA techniques. The environmental performance of specific countries is also assessed based on EPI (Environmental Performance Index), which is an integrated measure of how well they can handle environmental issues from the perspective of human health and the ecosystem [19]. Schultze and Trommer [20] emphasize that empirical studies make use of multiple environmental performance measures selected mainly based on practicability.

A significant research gap exists in a comprehensive assessment of this phenomenon at the level of sectors of the economy with a key impact on the environment. Without any doubt, agriculture can be deemed such a sector. A significant role of agriculture in implementing the concept of sustainable development prompted the authors of this paper to investigate the methods for evaluating the green performance of agriculture. In this paper, this term is defined as all positive effects of the environmental impact of the agricultural sector connected with preventing and reducing the emissions of pollutants, a sustainable use of resources and measures aimed at greening agriculture (including the development of the renewable energy sector and organic agriculture), to ensure sustainability of the whole agroecosystem.

The relationships between agriculture and the environment are reflected by agrienvironmental indicators $(A E I)$. They have become increasingly important for measuring the environmental consequences of agricultural practices and monitoring of progress towards sustainable development $[1,4,21,22]$. The characteristic of $A E I$ methods is that they provide a conceptual framework to define and bring together a set of agri-environmental indicators [23]. The methods of evaluation based on a set of indicators were elaborated at international [24] and domestic [25,26] level but also at regional [23] and farm [27-29] level as well as with reference to agricultural systems $[28,30]$. The general framework of and approach to the set of agri-environmental indicators were designed by the Organization for Economic Co-operation and Development [31]. They were assigned to six groups of indicators: soil, water, air, biodiversity, farm management, and agricultural inputs. The indicators were used in many scientific studies for evaluating a relationship between agriculture and the environment in selected countries [25]. Also, the European Commission, as a result of the IRENA (International Renewable Energy Agency) operation, identified 28 agri-environmental indicators $[32,33]$.

Considering the large diversity of agri-environmental factors, analyzing one or more specific indicators separately does not have major advantages [11]. Although studies concerning the evaluation of a relationship between agriculture and the natural environment do exist, they are usually limited to analyzing selected aspects only such as pesticides [34], nitrogen [35] and biodiversity [36]. On the other hand, there are no studies comprehensively approaching the issues of measuring the green performance of agriculture using an advanced set of indicators. The need for such research was also mentioned by Czyżewski et al. [37]. In view of the above-presented arguments, the purpose of this paper is the evaluation of the green performance of agriculture in 20 member states of the European Union. An aggregate index using multiple variables expressed as agricultural and environmental indicators was constructed. Therefore, this work is a genuine contribution to 
research concerning the evaluation of the environmental impact of the agricultural sector through designing a synthetic measure-the AEI. When constructing the synthetic index $(A E I)$, the linear ordering method with the median and standard deviation was applied. Thanks to this, this method is characterized by a high resistance to the occurrence of extreme observations, which is particularly important from the point of view of comparative analysis of the EU countries [38-40].

The authors try to answer the following questions: Is the Agri-Environmental Index an appropriate tool for evaluating the green performance of agriculture? What is the overall situation in this matter in EU countries? Which areas in terms of the impact of agriculture on the environment require remedial actions? The following structure was adopted in the paper. The next chapter presents the construction method of the $A E I$ index. In the third part, based on the values of the indexes, a comparative analysis of selected EU countries was carried out, the results obtained were discussed and the directions for further research were indicated. The last part contains conclusions drawn from the analyses.

\section{Materials and Methods}

The main aim of the research was to construct a synthetic index of green performance of agriculture $(A E I)$. This measure takes into account the multi-line impact of agriculture on the natural environment, with a particular focus on energy issues. The index was constructed using a taxonomic linear ordering method based on median and standard deviation $[41,42]$.

Methods of constructing synthetic measures are the subject of numerous publications [41,43-45]. Based on these foundations, the AEI index was designed by using the following procedure $[40,44]$ :

1. The selection as well as construction of the partial indicators describing an agrienvironmental performance from the OECD and Eurostat database;

2. The standardization of the indicators according to their impact (stimulants/destimulants) on the phenomenon studied (green performance of agriculture);

3. The construction of the synthetic measure; $A E I$ indexes for respective countries;

4. The linear hierarchization of selected EU countries, based on the AEI.

The problems that arise when selecting the indicators are primarily the difficulty in their proper defining and the lack of available data. For this reason, the agri-environmental indicators from the OECD and Eurostat databases were used. Ultimately, according to the data availability, 16 indicators (Table 1) and 20 countries were selected for the AEI calculation. The average values for the reference years, 2008-2017 were chosen for the analysis. Since some agri-environmental indicators are given in absolute values, to ensure their comparability, they were relativized, e.g., by converting them to a unit of agricultural land area in a given country. The indicators used for designing the synthetic measure were selected to reflect the multi-directional relations between this sector and the natural resources (earth, water, and air).

A significant role in the adopted set of partial indicators is ascribed to energy efficiency indicators: Total final energy consumption in agriculture and production of renewable energy from agriculture. Taking the first of the above-mentioned indicators into account relates to the fact that agriculture, as an energy user, contributes to the depletion of nonrenewable energy resources and to global warming through energy-related emissions [46]. In this context, the need for minimizing the expenditure of energy in the agricultural sector has been identified [47]. Biological, technical and technological progress in agricultural production contributes to increasing efficiency of production but at the same time leads to increasing energy expenditure connected primarily with consumption of energy accumulated in the means of production. The adopted indicator refers to the direct use of energy by agriculture. It comprises all energy carriers used directly in the process of agricultural production, including electricity, refined oil products, fuels derived from natural gas, and renewable fuels [48]. The second indicator considered in the studies shows that the agricultural sector both emits greenhouse gas and consumes energy but at the same time has 
a potential to generate renewable energy. Due to the wide variety of renewable energy resources that can be processed in agriculture, this sector can play a significant role both in generating energy and implementing the objectives of the climate policy [49].

Table 1. Indicators selected for the analysis.

\begin{tabular}{|c|c|c|c|}
\hline $\begin{array}{l}\text { Indicator } \\
\text { Symbol }\end{array}$ & Indicator Name (Unit of Measure) & $\begin{array}{l}\text { Stimulant/ } \\
\text { Destimulant }\end{array}$ & Characteristic/Impact on the Environment \\
\hline$x_{1}$ & $\begin{array}{l}\text { Nitrogen balance (inputs-outputs) } \\
\text { (kg/ha) }\end{array}$ & $\mathrm{D}$ & $\begin{array}{l}\text { a positive nitrogen balance increases the risk of soil, } \\
\text { water, and air pollution }\end{array}$ \\
\hline$x_{2}$ & $\begin{array}{l}\text { Phosphorus balance } \\
\text { (inputs—outputs) (kg/ha) }\end{array}$ & $\mathrm{D}$ & $\begin{array}{l}\text { a positive phosphorus nitrogen balance increases the } \\
\text { risk of soil, water, and air pollution }\end{array}$ \\
\hline$x_{3}$ & $\begin{array}{l}\text { Total sales of agricultural pesticides } \\
(\mathrm{kg} / \mathrm{ha})\end{array}$ & $\mathrm{D}$ & $\begin{array}{l}\text { the greater the use of pesticides, the greater the risk } \\
\text { of environmental pollution }\end{array}$ \\
\hline$x_{4}$ & $\begin{array}{l}\text { Agriculture freshwater abstraction } \\
\left(\mathrm{m}^{3} / \mathrm{ha}\right)\end{array}$ & $\mathrm{D}$ & $\begin{array}{l}\text { the greater the abstraction, the greater the pressure } \\
\text { on the environment }\end{array}$ \\
\hline$x_{5}$ & $\begin{array}{l}\text { Irrigation area (\% total agriculture } \\
\text { land area) }\end{array}$ & $\mathrm{S}$ & $\begin{array}{l}\text { areas actually irrigated; irrigation infrastructure } \\
\text { reduces water abstraction+ }\end{array}$ \\
\hline$x_{6}$ & $\begin{array}{l}\text { Irrigable area (\% total agriculture } \\
\text { land area) }\end{array}$ & $S$ & $\begin{array}{l}\text { areas with irrigation infrastructure, but not always } \\
\text { irrigated; irrigation infrastructure reduces water } \\
\text { abstraction }\end{array}$ \\
\hline$x_{7}$ & $\begin{array}{l}\text { Permanent pasture }(\% \text { total } \\
\text { agriculture land area) }\end{array}$ & $S$ & $\begin{array}{l}\text { promote biodiversity, regulate biochemical cycles, } \\
\text { and limit the transfer of nitrogen to waters }\end{array}$ \\
\hline$x_{8}$ & $\begin{array}{l}\text { Organic farming (\% total agriculture } \\
\text { land area) }\end{array}$ & $\mathrm{S}$ & $\begin{array}{l}\text { processes related to organic farming favour the } \\
\text { minimization of pollution and waste }\end{array}$ \\
\hline$x_{9}$ & $\begin{array}{l}\text { Total final energy consumption in } \\
\text { agriculture } \\
\text { (kg of oil equivalent (toe)/ ha) }\end{array}$ & $\mathrm{D}$ & $\begin{array}{l}\text { the less energy consumption, the less pressure on the } \\
\text { environment }\end{array}$ \\
\hline $\mathrm{x}_{10}$ & $\begin{array}{l}\text { Agricultural ammonia }\left(\mathrm{NH}_{3}\right) \\
\text { (\% of total ammonia emissions) }\end{array}$ & $\mathrm{D}$ & $\begin{array}{l}\text { ammonia emissions cause air pollution, negatively } \\
\text { affecting the quality of soil and water as well as } \\
\text { biodiversity }\end{array}$ \\
\hline$x_{11}$ & $\begin{array}{l}\text { Total greenhouse gas emissions from } \\
\text { agriculture } \\
\text { (\% of total emissions) }\end{array}$ & $\mathrm{D}$ & $\begin{array}{l}\text { increase in greenhouse gas emissions contributes to } \\
\text { the global warming }\end{array}$ \\
\hline$x_{12}$ & Farmland Birds Index (index) & $\mathrm{S}$ & a higher index favours biodiversity \\
\hline$x_{13}$ & $\begin{array}{l}\text { Agricultural land classified as having } \\
\text { low wind erosion risk }(\%)\end{array}$ & S & $\begin{array}{l}\text { wind erosion destroys fertile topsoil and organic } \\
\text { matter, deposits unwanted nutrients and salt, } \\
\text { threatening plants and animals }\end{array}$ \\
\hline$x_{14}$ & $\begin{array}{l}\text { Agricultural land classified as having } \\
\text { moderate water erosion risk }(\%)\end{array}$ & S & $\begin{array}{l}\text { water erosion negatively affects the soil, plants, and } \\
\text { wildlife, as well as the water quality itself }\end{array}$ \\
\hline$x_{15}$ & $\begin{array}{l}\text { Renewable energy production from } \\
\text { agriculture } \\
\text { (\% of total production) }\end{array}$ & S & $\begin{array}{l}\text { the higher the share of energy production from } \\
\text { renewable sources, the lower the pressure on the } \\
\text { environment (use of non-renewable resources, } \\
\text { environmental pollution, climate change) }\end{array}$ \\
\hline$x_{16}$ & $\begin{array}{l}\text { Organic carbon content in arable land } \\
\text { (tonnes/ha) }\end{array}$ & $\mathrm{D}$ & $\begin{array}{l}\text { high carbon deposits in the soil increase the risk of } \\
\text { greenhouse gas emissions }\end{array}$ \\
\hline
\end{tabular}

Source: own elaboration based on the OECD and Eurostat database.

Based on the characteristics of the agri-environmental indicators in the OECD and Eurostat database [50,51], eight were considered to be larger-the-better characteristics (stimulants) with a positive influence on the synthetic measure, and eight were regarded as 
smaller-the-better characteristics (de-stimulants) which reduced the AEI [52]. The values of the variables describing respective countries are presented as a matrix of observations:

$$
X=\left[\begin{array}{ccc}
x_{11} & \cdots & x_{1 m} \\
\vdots & \ddots & \vdots \\
x_{n 1} & \cdots & x_{n m}
\end{array}\right]
$$

As the diagnostic data set contained indicators that could not be directly aggregated, they were standardized using the zero unitarization method [53]:

For stimulants:

$$
z_{i j}=\frac{x_{i j}-\min \left(x_{i j}\right)_{i}}{\max \left(x_{i j}\right)_{i}-\min \left(x_{i j}\right)_{i}}
$$

For de-stimulants:

$$
z_{i j}=\frac{\max \left(x_{i j}\right)_{i}-x_{i j}}{\max \left(x_{i j}\right)_{i}-\min \left(x_{i j}\right)_{i}}
$$

where:

$z_{i j}$ is the normalized value of the $j$-th variable in the $i$-th country;

$x_{i j}$ is the initial value of the $j$-th variable in the $i$-th country.

This method was chosen because it was the only one that met all seven postulates formulated with regard to the use of standardization Equations, i.e., (1) elimination of labels describing the features; (2) order of magnitude of variables allowing comparison; (3) equal length of the variation interval for all standardized features (constant range) and equal lower and upper limit of their variation interval; (4) possibility of standardizing features that are both positive and negative and features that are only negative; (5) possibility of standardizing features with values close to zero; (6) non-negativity of values of the standardized features; (7) existence of simple formulas normalizing the nature of features [54]. Diagnostic features standardized as described above get values from 0 to 1 . The closer to 1 , the better the situation in terms of the analyzed feature, and the closer to 0 , the worse the situation. Standardization results for individual indicators and countries can be found in Supplementary Materials, Annex S1.

The normalized values of agri-environmental indicators were the basis for calculating the median and the standard deviation for each of the selected EU countries. The median values were determined using the formula $[38,39]$ :

$$
M e_{i}=\frac{z_{\left(\frac{m}{2}\right) i}+z_{\left(\frac{m}{2}+1\right) i}}{2}
$$

For an even number of observations, or:

$$
M e_{i}=z_{\left(\frac{m}{2}+1\right) i}
$$

For an odd number of observations, where:

$z_{i(j)}$ is the $j$-th statistical ordinal for the vector $\left(z_{i 1}, z_{i 2}, \ldots, z_{i m}\right), i=1,2, \ldots, n ; j=1,2$, $\ldots, m$.

In turn, the standard deviation values were calculated according to the following formula:

$$
S e_{i}=\sqrt{\frac{1}{m} \sum_{j=1}^{m}\left(z_{i j}-\bar{z}\right)}
$$

In the last step, the $A E I$ indexes for each country were developed (Supplementary Materials, Annex S1):

$$
A E I_{i}=M e_{i}\left(1-S e_{i}\right) A E I_{i}<1
$$


Values of the $A E I$ closer to 1 indicate a higher level of green performance of agriculture for the specific country, resulting in a higher rank. This allowed the comparison of the selected EU countries and classifying them into uniform groups according to their level of green performance:

$$
\text { group I : } A E I_{i} \geq \overline{A E I}+S \text { high level }
$$

group II : $\overline{A E I}+S>A E I_{i} \geq \overline{A E I}$ medium-high level

group III : $\overline{A E I}>A E I_{i} \geq \overline{A E I}-S$ medium-low level

$$
\text { group IV : } A E I_{i}<\overline{A E I}-S \text { low level }
$$

where $\overline{A E I}$ is the mean value of the synthetic measure, and $S$ is the standard deviation of the synthetic measure.

\section{Results and Discussion}

The synthetic measure describing the level of green efficiency of agriculture using the presented method was calculated for 20 member states of the European Union. Table 2 presents a division of the member states into four groups depending on the adopted value of the measure. On the other hand, Figure 1 presents a ranking of the analyzed member states according to the value of the aggregate measure. The studies show that the mean $A E I$ for the analyzed EU member states was 0.3069. It can therefore be concluded that the level of green efficiency of agriculture in the analyzed group of EU countries is very low. Simultaneously, a high variability in the analyzed phenomenon is noticeable between countries covered by the study. This is demonstrated by the fact that the values of $A E I$ deviated from the mean value by 0.0880 . The analysis of the four identified groups of countries leads to the conclusion that group I, characterized by the highest level of ecoefficiency of the analyzed sector, is represented by three countries, i.e., Portugal (0.4931), Austria (0.4144) and Greece (0.4139). An identical number of countries was recorded in the group in which the level of the analyzed phenomenon was the lowest. That group comprised Hungary, Lithuania, and Belgium. In Belgium, as the country with the lowest level of green efficiency of agriculture, $A E I$ was only 0.1358 . Eight countries presented a medium-high level of agriculture eco-efficiency, including four member states that joined the EU in 2004 or later (Slovak Republic, the Czech Republic, Slovenia, and Latvia). A medium-low level of the analyzed phenomenon was observed for six countries. A deeper analysis of agri-environmental indicators shows that the main problems in this regard relate to:

- The high share of agricultural lands classified as having high water and wind erosion risk (average $z_{i}$ for 20 countries: respectively 0.1314 and 0.1383 ),

- The irrigation (0.1890) and irrigable (0.2465) rates of agricultural land areas,

- The low share of the renewable energy from agriculture (0.3059) as well as organic farming (0.3081),

- The high rates of agriculture sector in ammonia $\left(\mathrm{NH}_{3}\right)$ emissions.

Table 2. Classification of $20 \mathrm{EU}$ member states according to the value of the $A E I$.

\begin{tabular}{cccl}
\hline Group Number & Green Performance Level & AEI Range & Countries \\
\hline I & high & $0.3950-$ & Portugal, Austria, Greece \\
\hline II & medium-high & $0.3069-0.3950$ & $\begin{array}{l}\text { Slovak Republic, Czech Republic, Slovenia, } \\
\text { Germany, Spain, Latvia, Netherlands, Sweden }\end{array}$ \\
\hline III & medium-low & $0.2189-0.3069$ & $\begin{array}{l}\text { United Kingdom, Denmark, France, Estonia, } \\
\text { Luxembourg, Poland }\end{array}$ \\
\hline IV & low & -0.2189 & Hungary, Lithuania, Belgium \\
\hline
\end{tabular}




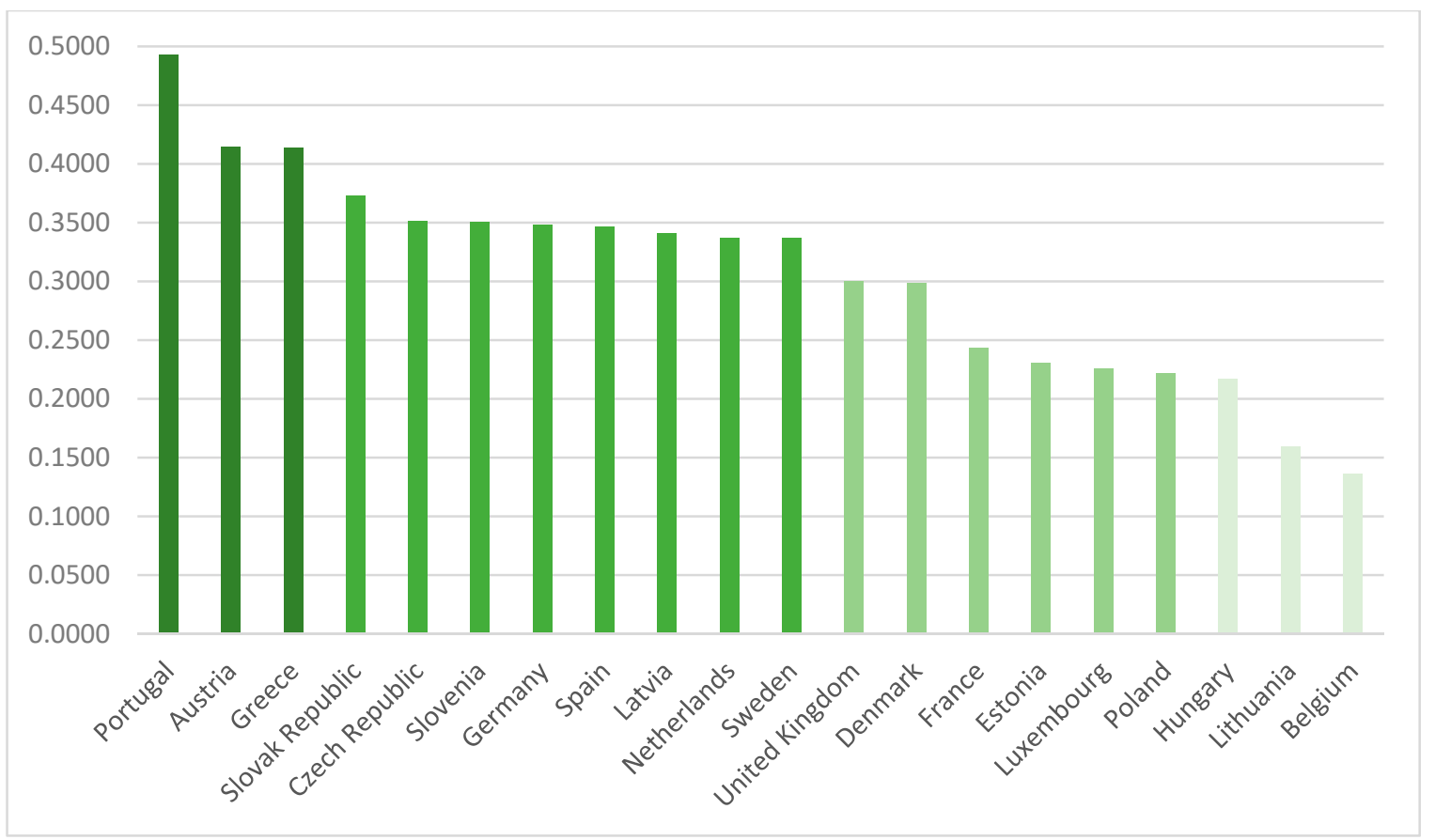

Figure 1. Ranking of selected EU countries based on AEI.

The indicated areas require undertaking intensive corrective measures, and hence should be especially monitored by international and national institutions to outline action strategies for the agricultural sector in the following years.

On the other hand, areas can be identified in which very good results have been already achieved, i.e., regarding the volume of water used for agricultural purposes (0.8693), regarding the use of pesticides (0.8446) or phosphorus balance indicator (0.7942). Another characteristic of agriculture in EU countries is a low consumption of final energy (0.7476) and a low emission of greenhouse gases (0.7155).

Considering the shape of energy efficiency indicators, on the one hand a very low share of agriculture in renewable energy production is still observed, so this indicator has a negative impact on the overall green performance of the agricultural sector ( $A E I)$, and on the other hand, agriculture in the analyzed EU countries features a low level of final energy consumption, which in turn improves green performance.

Looking closer at the countries, their weaknesses and strengths regarding green performance can be identified. Portugal, scoring best out of 20 member states of the EU, predominantly owes its success to high scores $(0.8000-1.0000)$ earned for 5 indicators, including: the share of agriculture in total ammonia emissions, biodiversity of agricultural areas, relatively low consumption of final energy in agriculture and low content of organic carbon in arable land. On the other hand, indicators of wind and water erosion and activities to increase the production of energy from renewable sources need to be improved. In turn, Belgium was the country with the worst results $(0.0000-0.1000)$ in seven areas, i.e., water and wind erosion risk, irrigation, and irrigable areas, farmland bird index, total final energy consumption in agriculture and ammonia emissions from agriculture. Moreover, the average values (0.5000) were not exceeded for nine indicators (56.3\%).

The Benelux countries are characterized by a low balance of nitrogen in soil. The Netherlands and Belgium also had the highest pesticide use indicators. In contrast, in the south of Europe, i.e., in Greece, Spain, and Portugal, considerable amounts of water are used for agricultural needs, which should be certainly associated with the climate of these countries. As many as 15 out of 20 analyzed states (except Denmark, Portugal, Spain, the Netherlands and Greece) have a low share of areas subject to irrigation processes. Considering the structure of use of arable land, Hungary, the Netherlands, Luxembourg, 
the United Kingdom, France, and Poland were characterized by the lowest percentage of land for organic farming. As regards the share of agriculture in final energy consumption, countries with the worst score are the Netherlands, Belgium, and Luxembourg. In turn, Denmark, France, and Lithuania have the highest indicators of greenhouse gas and ammonia emissions.

Soil in EU member states contains about 79 billion tons of coal. The $\mathrm{CO}_{2}$ storage capacity is sensitive to climatic conditions, so there is a high risk that soils will become the main source of greenhouse gas emissions due to global warming [55]. For this reason, the $A E I$ was designed using the organic carbon content in arable land. The least coal in soil is found in Hungary, and the United Kingdom performs the worst in this respect. In contrast, the risk of erosion by wind and/or water is a problem that bothers all the analyzed countries to a greater or lesser degree. Taking into account the share of agriculture in renewable energy production the leaders are the Netherlands, Belgium, and Germany, while at the lower end of the ranking are Estonia, Sweden, and Slovenia.

When reviewing the existing literature, it is difficult to indicate studies that address the issue of a comprehensive evaluation of the green performance of agriculture, based on the construction of synthetic measures. The research conducted so far has focused mainly on the selection of one or several indicators. For instance, Szuba-Barańska [56] and Mrówczyńska-Kamińska investigated the impact of agriculture on the environment in Central and Eastern Europe. To this end, they used selected agri-environmental indicators only, including greenhouse gas emissions and general pollution of the environment (ammonia, methane, nitrous oxide, and carbon dioxide). Their studies revealed that Lithuania (alongside Romania and Latvia) was a country with the strongest negative impact of agriculture on the natural environment. The evidence is the highest level of emissions of greenhouse gases and air pollutants into the environment. The results of studies presented in this paper partly corroborate these observations as Lithuania ranks second to last in terms of green performance of agriculture. Ilić et al. [57] evaluated environmental performance of agriculture in EU countries based on the EPI for the problem area-Agriculture. They divided EU countries into three groups according to the value of EPI, taking nine problem areas into account, and two groups according to the area of agriculture. However, the index designed for agriculture consisted of two indicators only, i.e., nitrogen use efficiency and nitrogen balance. Due to the narrower range of indicators involved, this study only partly coincides with the study presented in this paper. However, the unfavorable position of Belgium and Luxembourg is confirmed. It is worth emphasizing that Belgium is a country with a high level of intensity of using technology in agriculture, which gives rise to several negative consequences in the form of adverse changes in the natural environment [58]. The agri-environmental indicators were also used by Turčeková et al. [59] for evaluating agrienvironmental performance in 27 member states of the EU. The authors applied a radial output-oriented DEA model in their study, taking into account the following variables: greenhouse gas emissions (as output), arable land, labor force, fertilizers consumption, and agricultural subsidies (as inputs). It was demonstrated that Slovakia, the Czech Republic, and Poland were countries with the highest environmental performance. One of the reasons for this fact was the low level of technology involved in agriculture. The studies focused solely on environmental performance from the point of view of a relationship between greenhouse gas emissions and production outlays. However, they did not provide a full image of the level of environmental performance of agriculture. This testifies to the reasonableness of seeking more comprehensive measures of the impact of agriculture on the natural environment.

The proposed synthetic index method allowed for a comprehensive and unambiguous assessment of the level of green performance of agriculture sectors. By analyzing individual indicators in the studied countries, the authors obtained information about the strengths and weaknesses of activities in this area in individual countries, while synthetic measures $(A E I)$ allowed for a comparison and general assessment of the level of this phenomenon in the EU countries. 
The conducted analysis has indicated potential directions for further research. Due to the large information gap, only $20 \mathrm{EU}$ countries were included. Individual countries show shortcomings in the reporting of individual agri-environmental indicators. Therefore, an important area of research should be the development of an effective information gathering system and the development of the existing set of indicators for an even more comprehensive assessment of green performance of agriculture. Moreover, it would be worth extending the existing analysis to include countries from other regions of the world (e.g., USA, China, Japan, Australia, South American countries).

\section{Conclusions}

New barriers, primarily deemed equivalent to exhaustion of natural resources, necessitated the verification of economic growth paradigms towards sustainable growth. This concept is essential for the agricultural sector that on the one hand relies on natural resources in the production process, and on the other hand has a significant impact on the environment. In the agricultural sector the production effects are associated with the emergence of various environmental hazards. Environmental protection is currently one of the priorities in EU policy and at the same time one of the major challenges for agriculture. The environmental effects of agricultural activity have been made a part of economic and agricultural research. An area that needs further investigation and deeper analysis is green performance of agriculture.

The evaluation of green performance of the agricultural sector is a complex issue, which makes it a difficult subject for analysis. As a multi-criterion concept, it requires aggregate measures based on integration of various impacts of agriculture on the environment. The added value of the research carried out lies in the development of a comprehensive method of evaluation the green performance of agriculture sector by constructing a synthetic index $(A E I)$. The information value of this index will allow for better integration and improvement of activities around monitoring, planning, and implementation of agricultural policy assumptions. At the same time, the analysis of synthetic measures of agri-environmental indicators made it possible to identify the strengths and weaknesses of green performance of agriculture both at the European and national levels.

When answering the research questions posed in the paper, it should be stated that the proposed method allows for an unambiguous assessment of the studied phenomenon, enabling a comparative analysis between individual countries. In response to the second question, it can be stated that the general level of green performance of agriculture is low, as demonstrated by the average $A E I$ value for all analyzed countries (0.3069). On the other hand, the analysis of the average standardized values of agri-environmental indicators shows that many aspects of agricultural activity require decisive intervention both at the national and international level. In the upcoming years, one of the main challenges should be increasing the share of agriculture in the production of energy from renewable sources as well as increasing the share of organic agriculture in the crop structure. Furthermore, dynamic action requires a high indicator of agriculture sector in ammonia $\left(\mathrm{NH}_{3}\right)$ emissions.

The limitations at the research stage, including the absence of data for certain agrienvironmental indicators and/or countries, point to lines of further actions and research. In the first place, it should be considered how the existing system for collecting data from the member states could be improved. This will allow comprehensive analyses of $A E I$. In addition, dynamic changes in the conditions of functioning of the agricultural sector will certainly necessitate developing the existing set of indicators. Further lines of research should take into account a wider range of variables to allow more accurate assessment of the effect of agriculture on the natural environment, especially in the context of the implemented energy policy.

Supplementary Materials: The following are available online at https:/ / www.mdpi.com/1996-1073/ 14/1/45/s1, Annex S1: Standardization of the agri-environmental indicators and the AEI calculation. 
Author Contributions: Conceptualization, A.K. and A.N.; methodology, A.K. and A.N.; formal analysis, A.K. and A.N.; resources, A.N. and A.K.; data curation, A.K.; writing—original draft preparation, A.N. and A.K.; writing-review and editing, A.N. and A.K.; visualization, A.K.; funding acquisition, A.N. and A.K. All authors have read and agreed to the published version of the manuscript.

Funding: The APC was funded by the University of Life Sciences, Faculty of Agrobioengineering, grant number RKA/S/8/2020 (EFI) and the vouchers.

Conflicts of Interest: The author declares no conflict of interest.

\section{References}

1. Piorr, H.P. Environmental policy, agri-environmental indicators and landscape indicators. Agric. Ecosyst. Environ. 2003, 98, 17-33. [CrossRef]

2. Pawłowska-Tyszko, J.; Pawłowski, M.; Konat, G. Environmental Protection Instruments in Polish Agriculture in the Context of Its Sustainable Development; Institute of Agricultural and Food Economics National Research Institute: Warsaw, Poland, 2018; pp. 36-39.

3. The Organisation for Economic Co-operation and Development (OECD). A Green Growth Strategy for Food and Agriculture; Preliminary Report; OECD Publishing: Paris, France, 2011.

4. United Nations Economic Commission for Europe (UNECE). Agri-Environmental Indicators. In Proceedings of the Committee on Environmental Policy Conference of European Statisticians, Geneva, Switzerland, 30 October-1 November 2012.

5. Nigel, J. Concepts of efficiency in ecological economics: Sisyphus and the decision maker. Ecol. Econ. 2006, 56, 359-372.

6. Tanentzap, A.J.; Lamb, A.; Walker, S.; Farmer, A. Resolving conflicts between agriculture and the natural environment. PLoS Biol. 2015, 13, e1002242. [CrossRef] [PubMed]

7. Klepacki, B.; Gołasa, P.; Wysokiński, M. Efficiency of greenhouse gas emissions in European Union agriculture. Village Agric. 2016, 3, 129-144.

8. Femia, A.; Hass, J.; Lumicisi, A.; Romeiro, A. Agri-Environmental Statistics and Indicators: A Literature Review and Key Agri/Environmental Indicators; Global Strategy Technical Report, No. 27; Food and Agriculture Organization of the United Nations: Rome, Italy, 2017.

9. Kremen, C.; Miles, A. Ecosystem services in biologically diversified versus conventional farming systems: Benefits, externalities, and trade-offs. Ecol. Soc. 2012, 17, 40. [CrossRef]

10. Pe'er, G.; Bonn, A.; Bruelheide, H.; Dieker, P.; Eisenhauer, N.; Feindt, P.H.; Hagedorn, G.; Hansjürgens, B.; Herzon, I.; Lomba, L.; et al. Action needed for the EU Common Agricultural Policy to address sustainability challenges. People Nat. 2020, 2, 305-316. [CrossRef]

11. Zhang, T.Q.; Zheng, Z.M.; Lal, R.; Lin, Z.Q.; Sharpley, A.N.; Shober, A.L.; Smith, D.; Tan, C.S.; Van Cappellen, P. Environmental indicator principium with case references to agricultural soil, water, and air quality and model-derived indicators. J. Environ. Qual. 2018, 47, 191-202. [CrossRef] [PubMed]

12. Ahtiainen, H.; Pouta, E.; Liski, E.; Myyrä, S.; Assmuth, A. Importance of economic, social, and environmental objectives of agriculture for stakeholders: A Meta-Analysis. Agroecol. Sustain. Food 2015, 39, 1047-1068. [CrossRef]

13. Musvoto, C.; Nortje, K.; De Wet, B.; Mahumani, B.K.; Nahman, A. Imperatives for an agricultural green economy in South Africa. S. Afr. J. Sci. 2015, 111, 1-8. [CrossRef]

14. Mutingi, M.; Mapfaira, H.; Monageng, R. Developing performance management systems for the green supply chain. J. Remanuf. 2014, 4, 6. [CrossRef]

15. Li, J.; Lin, B. Green Economy Performance and Green Productivity Growth in China's Cities: Measures and Policy Implication. Sustainability 2016, 8, 947. [CrossRef]

16. Gallego-Álvarez, I.; Vicente-Galindo, M.P.; Galindo-Villardón, M.P.; Rodríguez-Rosa, M. Environmental Performance in Countries Worldwide: Determinant Factors and Multivariate Analysis. Sustainability 2014, 6, 7807-7832. [CrossRef]

17. Duit, A. Understanding Environmental Performance of States: An Institution Centered Approach and Some Difficulties; Working Paper Serie 7; Göteborg University: Göteborg, Sweden, 2005.

18. Beltrán-Estevea, M.; Picazo-Tadeob, A.J. Assessing environmental performance in the European Union: Ecoinnovation versus catching-up. Energy Policy 2017, 104, 240-252. [CrossRef]

19. Emerson, J.W.; Hsu, A.; Levy, M.A.; de Sherbinin, A.; Mara, V.; Esty, D.C.; Jaiteh, M. Environmental Performance Index and Pilot Trend Environmental Performance Index; Yale Center for Environmental Law and Policy: New Haven, CT, USA, 2012.

20. Schultze, W.; Trommer, R. The concept of environmental performance and its measurement in empirical studies. J. Manag. Control 2011, 22, 375-412. [CrossRef]

21. Riley, J. The indicator explosion: Local need and international challenges. Agric. Ecosyst. Environ. 2001, 87, 119-120. [CrossRef]

22. Bockstaller, C.; Guichard, L.; Makowski, D.; Aveline, A.; Girardin, P.; Plantureux, S. Agri-environmental indicators to assess cropping and farming systems. A review. Agron. Sustain. Dev. 2008, 28, 139-149. [CrossRef]

23. Payraudeau, S.; Van der Werf, H.M.G. Environmental impact assessment for a farming region: A review of methods. Agric. Ecosyst. Environ. 2005, 107, 1-19. [CrossRef]

24. Delbaere, B.; Serradilla, A.N.E. Environmental Risks from Agriculture in Europe: Locating Environmental Risk Zones in Europe Using Agri-Environmental Indicators; EC NC-European Centre for Nature Conservation: Tilburg, The Netherlands, 2004. 
25. Rigby, D.; Woodhouse, P.; Young, T.; Burton, M. Constructing a farm level indicator of sustainable agriculture agriculture practice. Ecol. Econ. 2001, 39, 463-478. [CrossRef]

26. Saunders, C.M.; Kaye-Blake, W.; Campbell, R.; Benge, J. Agricultural Environmental Indicators: Using OECD Agri-Environmental Indicators to Assess New Zealand Kiwifruit Orchards. In Proceedings of the 15th New Zealand Agricultural and Resource Economics Society Conference, Nelson, New Zealand, 27-28 August 2009.

27. Van der Werf, H.G.M.; Petit, J. Evaluation of environmental impact of agroculture at the farm level: A comparison and analysis of 12 indicator-based methods. Agric. Ecosyst. Environ. 2002, 93, 131-145. [CrossRef]

28. Halberg, N.; Verschuur, G.; Goodlass, G. Farm level environmental indicators; are they useful? An overview of green accounting systems for European farms. Agric. Ecosyst. Environ. 2005, 105, 195-212. [CrossRef]

29. Meyer-Aurich, A. Economic and environmental analysis of sustainable farming practices-A Bavarian case study. Agric. Syst. 2005, 86, 190-206. [CrossRef]

30. Clark, M.; Tilman, D. Comparative analysis of environmental impacts of agricultural production systems, agricultural input efficiency, and food choice. Environ. Res. Lett. 2017, 12, 064016. [CrossRef]

31. The Organisation for Economic Co-operation and Development (OECD). Environmental Performance of Agriculture in OECD Countries Since 1990; OECD Publications: Paris, France, 2008.

32. European Commission. Development of Agri-Environmental Indicators for Monitoring the Integration of Environmental Concerns into the Common Agricultural Policy; Commission Communication COM; European Commission: Brussels, Belgium, 2006.

33. European Environment Agency (EEA). Agriculture and Environment in EU-15-The IRENA Indicator Report; European Environment Agency Report, No. 6; Office for Official Publications of the European: Copenhagen, Denmark, 2005.

34. Reus, J.; Leenderste, P.; Bockstaller, C.; Fomsgaard, I.; Gutsche, V.; Lewis, K.; Nilsson, C.; Pussemier, L.; Trevisan, M.; van der Werf, $\mathrm{H}$; et al. Comparing and evaluating eight pesticide environmental risk indicators developed in Europe and recommendations for future use. Agric. Ecosyst. Environ. 2002, 90, 177-187. [CrossRef]

35. Buczko, U.; Kuchenbuch, R.O. Environmental indicators to assess the risk of diffuse nitrogen losses from agriculture. Environ. Manag. 2010, 45, 1201-1222. [CrossRef] [PubMed]

36. Bockstaller, C.; Lassere-Joulin, F.; Slezack-Deschaumes, S.; Piutti, S.; Villerd, J.; Amiaud, B.; Plantureux, S. Assessing biodiversity in arable farmland by means of indicators: An overview. OCL 2011, 18, 137-144. [CrossRef]

37. Czyżewski, B.; Matuszczak, A.; Muntean, A. Influence of agricultural policy on the environmental sustainability of European farming. J. Environ. Prot. Ecol. 2018, 19, 426-434.

38. Strahl, D. Methods for Evaluation of Regional Development (Metody Oceny Rozwoju Regionalnego); AE Publishing House: Wrocław, Poland, 2006.

39. Grzebyk, M.; Stec, M. Sustainable Development in EU Countries: Concept and Rating of Levels of Development. Sustain. Dev. 2015, 23, 110-123. [CrossRef]

40. Kasztelan, A. How Circular Are the European Economies? A Taxonomic Analysis Based on the INEC (Index of National Economies' Circularity). Sustainability 2020, 12, 7613. [CrossRef]

41. Hellwig, Z. The Application of the Taxonomic Method to the Typological Division of Countries by Level of their Development as Well as Resources and Structure of Qualified Staff. (Zastosowanie metody taksonomicznej do typologicznego podziału krajów ze względu na poziom ich rozwoju oraz zasoby i strukture wykwalifikowanych kadr). Przeglad Stat. 1968, 4, 307-326.

42. Łogwiniuk, K. The Use of Taxonomic Methods in the Comparative Analysis of the Access to the ICT Infrastructure by Schoolchildren in Poland. Econ. Manag. 2011, 3, 7-23.

43. The Organisation for Economic Co-operation and Development (OECD). Handbook on Constructing Composite Indicators; Methodology and User Guide; OECD Publishing: Paris, France, 2008.

44. Piotrowska, E.; Roszkowska, E. Analysis of the Diversity of Polish Voivodeships in Terms of the Level of Innovation (Analiza zróżnicowania województw Polski pod względem poziomu innowacyjności). Optim. Studia Ekon. 2011, 2, 65-85.

45. Godlewska, J.; Sidorczuk-Pietraszko, E. Taxonomic Assessment of Transition to the Green Economy in Polish Regions. Sustainability 2019, 11, 5098. [CrossRef]

46. Eurostat. Agri-Environmental Indicator-Energy Use. Available online: https://ec.europa.eu/eurostat/statistics-explained/ index.php/Agri-environmental_indicator_-_energy_use (accessed on 10 April 2020).

47. Harchaoui, S.; Chatzimpiros, P. Can Agriculture Balance Its Energy Consumption and Continue to Produce Food? A Framework for Assessing Energy Neutrality Applied to French Agriculture. Sustainability 2018, 10, 4624. [CrossRef]

48. Gołaszewski, J. (Ed.) Efektywność Energetyczna w Rolnictwie Europejskim-Studium Przypadków Energy Efficiency in European Agriculture-Case Studies; UWM Publishing House: Olsztyn, Poland, 2013.

49. Sulewski, P.; Majewski, E.; Was, A. The importance of agriculture in the renewable energy production in Poland and the EU. Probl. Agric. Econ. 2017, 1, 50-74.

50. OECD. Available online: https://stats.oecd.org/ (accessed on 18 October 2020).

51. Eurostat. Available online: https:/ / ec.europa.eu/eurostat/data/database (accessed on 18 April 2020).

52. Kasztelan, A.; Nowak, A.; Hawlena, J. Green Growth in Agriculture in the European Union: Myth or Reality. Eur. Res. Stud. J. 2019, 22, 35-48. [CrossRef]

53. Kijek, A. Sector Risk of the Processing Industry. In Modeling and Assessment (Ryzyko Sektorowe Przemystu Przetwórczego: Modelowanie i Ocena); UMCS Publishing House: Lublin, Poland, 2013. 
54. Jarocka, M. The Choice of a Formula of the Data Normalization in the Comparative Analysis of Multivariate Objects (Wybór formuły normalizacyjnej w analizie porównawczej obiektów wielocechowych). Econ. Manag. 2015, 1, 113-126.

55. Jones, A. The European Environment State and Outlook 2010; Publications Office of the European Union: Luxembourg, 2010.

56. Szuba-Barańska, E.; Mrówczyńska-Kamińska, A. An attempt to assess the impact of agriculture on the environment in the countries of Central-Eastern Europe. J. Agribus. Rural Dev. 2016, 3, 401-412. [CrossRef]

57. Ilić, I.; Krstić, B.; Jovanović, S. Environmental performances of agriculture in the European Union countries. Econ. Agric. 2017, 64, 41-55.

58. Nowak, A.; Krukowski, A.; Różańska-Boczula, M. Assessment of sustainability in agriculture of the European Union countries. Agronomy 2019, 9, 890. [CrossRef]

59. Turčeková, N.; Svetlanská, T.; Kollár, B.; Záhorský, T. Agri-Environmental Performance of EU Member states. Agris On-Line Pap. Econ. Inform. 2015, 7, 199-208. [CrossRef] 